\title{
Influence Factors Cultural Factors Social Factors Characteristic Individual And Psychological Factor On The Decision Purchase Of Car Toyota Avanza In Makassar.
}

\author{
Jeny Kamase \\ University Moeslem Indonesia
}

\begin{abstract}
This study aims to demonstrate empirically the Influence of cultural factors, social factors, individual characteristics factors and psychological factors Decision Against Toyota Avanza car purchases in Makassar. The first hypothesis proposed in this study is the cultural factors, social factors, individual characteristics factors, psychological factors influence the purchasing decision of Toyota Avanza. The second hypothesis proposed is characteristic factors and psychological factors have a dominant influence on the decision pembelia Toyota Avanza. The method used in this research is method survey of 100 respondents. The entire population in this study used as a sample by census. The data used is data p Rimer and processed using multiple linear regression statistical tests with SPSS. The results of this study prove that the first hypothesis which states the competence effect on audit quality is acceptable and significant at $\alpha=0.05$. The second hypothesis which states affect the independence of audit quality is acceptable and significant at $\alpha=0.05$.
\end{abstract}

Keywords: Cultural factors, social factors, individual characteristics factors and psychological factors and the purchase decision.

\section{Preliminary}

Behaviors consumers (consumer behavior) is the activities of individuals who are directly involved in obtaining and using goods and services are in the process of decision-making on the preparation and determination of these activities. Conjunction with the decision of purchasing a product or service, understanding of consumer behavior include answers to questions such as what (what) you bought, where the purchase (where), how habits (how Often) to buy and in what circumstances (under what condition) goods and services purchased. The company's success in marketing needs to be supported by a good understanding of consumer behavior, because understanding of consumer behavior can design whatever the customer wants (Mangkunagara, 2009).

In meeting the needs and desires of consumers there are some important elements that must be considered is the consumer behavior in the sense that the process of decision making and physical activity all of which involve individuals in assessing, acquiring and using goods and services economically. Individuals who make purchases to meet the needs of personal or household consumption is called the final consumer. But that does not mean other people do not get involved in the process of purchasing.

In general, a consumer will buy the most preferred brand of a product. There are two factors that can arise between the intention and the purchase decision itself first factor is the attitude of others. The extent to which the attitude of others will affect a person's mind depends on the attitude of others towards the purchase decision and motivation itself to fulfill the wishes of others. The stronger the attitude of the other person and the closer he is on the decision makers, the effect will be even greater. Purchase intent is also influenced by factors of situational undesirable. Consumers form a purchase intent based on factors such as the expected revenues and expected benefits of the product. If consumers are almost act, an undesirable situation can change their purchase intention. Understanding consumer behavior and know the customers is not easy. Consumers may express their needs and desires, but rather the opposite. They may not understand the motivation in depth, and may respond influence to change their mind at the last minute.

Personal characteristics of consumers who are used to process the stimuli are very complex, and one of them is the motivation of consumers to buy. According to Schiffman and Kanuk (2004) states that motivation as a power boost from within the individual who force them to take action. If a person has high motivation towards a particular object, then he will be compelled to behave in control of the product. Conversely, if motivation is low, then he will try to avoid the object in question. The implication in marketing is to the possibility of the person interested in buying a product or brand marketing offer or not. Purchase decision is a step in the buyer's decision process in which consumers actually buy. This is an activity of individuals who are directly involved in obtaining and use of goods which he used, for example the purchase of cars that are the means of transportation modern society for those with $a$ highly mobile activity. 
One of the brands favored by some people since time is the Toyota brand. To face the competition of Toyota products always create new discoveries which adapted to the changing times and the desire of the public to remain salable products. Toyota became Best Ideal Indonesian Family Car, The type of family car into Best Ideal Indonesian Family Car consisting of k elas sedan and SUV sort of Avanza, Innova, Harir, Rush, Camry and Vios. In price, the most interest is the brand Avanza, the grounds are reasonably priced, fashionable design as well as easier and more convenient, especially for middle and lower. Toyota is one of the largest car manufacturers in Indonesia, providing evidence that Toyota has always been a market leader for the national automotive market competitors. Sales of all brands of vehicles nationally has exceeded 500 thousand units until the seventh month of 2011, with details of the total retail sales of 503879 units, while wholesale sales as many as 506742 units (www.poskota.co.id ).

According to Interbrand's Best Global Brands Report 2011 Toyota remains the best brand is positioned throughout 2011 with 11 and Mercedes Benz and BMW is positioned $12,$. This proves that Toyota remained consistently maintained as the best brand throughout the years can not be separated from the top 15 rankings. In 2011, Toyota managed to rise six per cent from 2010 with a value USD27,8 billion. Although hit by natural disasters and the decline in sales in 2011 many of the problems that confront Toyota. But Toyota has remained consistent to the product development as well as security and quality. These two steps is the most dominant in helping to restore the reputation for quality that is extraordinary ( www.astra-motor.com ).

One way to expand the market share of Toyota brand cars is to develop new products, one of which is the Toyota Avanza. Toyota Avanza is a product development conducted by PT Toyota Astra Motor in its efforts to mendifferensiasikan products. Toyota Avanza was designed as a family car and commerce with the highest sales figures nationally ( www.ujungpandangekspress.com ).

Seeing these conditions lead to businesses increasingly required to have the right strategy to meet the target sales volume. Given the increasingly dynamic development of technology, people are required to quickly and precisely to act so as not to compete. According to Kotler (2002), in increasing competition each company should be able to win this competition by displaying the best products and can meet consumer tastes are always evolving and changing. Along with the development and the increasing need for transportation to bring fresh air tools for automotive companies, this is an opportunity for market share. Products offered by the company can be one of the formation of motivations, perceptions and attitudes of consumers in making purchasing decisions. Besides, it is easy to get the kind of car transportation tool is currently very easy because credit granting program can be done with an advance that is affordable by all levels of society.

Based on the above phenomenon that is increasing sales of Toyota Avanza as personal transportation are much in demand and increased competition for customers by providing a wide range of easiness obtain a car then the writer is interested in studying "Factors Influencing Purchase Decision Toyota Avanza in Makassar ".

\section{Literature Review}

Definition of Marketing according to Kotler (2005), can be distinguished social and managerial. Socially, marketing is defined as a social process with the process of individuals and groups obtain what they need and want with the creation of offering and freely exchanging products and services of value with others.

Definition managerially marketing is marketing as the art of selling products but the sales process is not an essential part of marketing seller is just the tip of the marketing. The marketing concept according to Kotler (2005), confirms that the key to achieving the organization's goals are a company should be more effective than competitors in creating, submitting, and communicate the value of customers in selected target markets. Kotler (2005), confirms that the key to achieving the organization's goals are a company should be more effective than competitors in creating, submitting, and communicating customer value pa da selected target markets. The marketing strategy is a way to achieve the goals of a company. It is also supported by the opinion Swastha (1996) "The strategy is a series of grand design which illustrates how a company should operate to achieve its objectives. Furthermore, according to Kotler (2005), the strategy is a game plan for achieve the desired goal by a company or a business unit. Strategy is a plan for a unified, comprehensive, and integrated connecting excellence corporate strategy with environmental challenges and are designed to ensure that the main purpose of the company can be achieved through appropriate strategies of an organization. Tjiptono (2002) states that there are at least three strategies scope which made reference marketing is marketing strategies, marketing strategies element, product-market entry strategies. Marketing strategies focused the marketing variables such as market segmentation, identification and selection target markets, positioning and marketing mix. Marketing strategies include elements of individual elements of the marketing mix, for example, the promotion strategy 'pushversus pull' distribution strategy 'intensive, selectif or exclusive', and strategy pricing 'penetration versus skimming price'. While product-market entry strategies include a strategy to maintain market sa pang, harvest market share. According to Kotler (2000), building a strategy marketing is an attempt to formulate the business of business competition, the targets that should be achieved and the wisdom that is already available to achieve these targets. There are four main keyword need to be 
considered by a company in determining the competitive strategies for success, namely: (1) the strengths and weaknesses of the company, (2) the value of human resources as the key players, (3) opportunities and hambatandalam industry, and (4) community and social. The decision making process begins with the requirement that seeks to fulfill. Meeting these needs is associated with several alternatives that need to be evaluated aimed at obtaining the best alternative of consumer perception. In the process of comparing these consumers need information that the number and importance depending on the needs of consumers and situations. Purchasing decisions will be made by using the rules of balancing the positive side to the negative side of a brand (compensatory decision rule) or to seek the best solution from a consumer perspective (noncompensatory decision rule), which will be re-evaluated after consumption. Models of decision-making have been developed by some experts to understand how a consumer's purchasing decision. The models emphasize the contemporary decision making to actors who play a role in decision-making is the consumer, as well as more expensive psychological and social aspects of the individual.

Generally there are three ways / models of consumer decision-making analysis, namely: Economic Models, decisions are taken based on economic reasons and are more rational. Psychological models, more taken for reasons psikoligs and a number faktos sosilogis such as family and cultural influences. Consumer behavior models. Models are generally taken most consumers, Ruled faktos ekonimis rational and psychological. A buyer's decision was also influenced by his personality characteristics, including age, occupation, state of the economy. Consumer behavior will determine the decision-making process in making a purchase. According to Kotler (2000) there are several stages in taking a decision to make a purchase.

\section{Research Methods}

This type of research is descriptive quantitative to identify and analyze factors such as cultural, social level, the individual characteristics and psychological factors on purchase decision of Toyota Avanza in the city of Makassar. According Sugiyono (2005) descriptive study was conducted to determine the value of the independent variables either one variable or more without making comparisons or linking to other variables.

According Indriantoro and Supomo (2002) primary data is data that comes directly from the source data collected specifically and direct relationship with the problems studied. Primary data in this penenitian is data obtained through direct interviews with owners of Toyota Avanza through field surveys based on questionnaires. Secondary data is data obtained from the data collection Data collection is done by reading literature books, journals, internet, magazines and previous research related to the research.

\section{Results And Discussion}

This research uses descriptive analysis to provide an explanation that facilitate in interpreting the results of further analysis. One way to classify these data and presenting it in the form of a table. From the results of the questionnaire answers are correct and complete by the respondent, then the next step is to-analysis of respondents' identities based on age, sex, years of service, and level of education, can be seen in table 1 .

Table 1 : Classification based Identity Respondents

\begin{tabular}{|c|c|c|}
\hline Information & amount Person & Percentage \\
\hline $\begin{array}{l}\text { Age: } \\
\text { 20-29 Years } \\
\text { 30-39 Years } \\
\geq 40 \text { Years }\end{array}$ & $\begin{array}{c}0 \\
45 \\
55\end{array}$ & $\begin{array}{c}0 \% \\
45 \% \\
55 \%\end{array}$ \\
\hline $\begin{array}{l}\text { Gender: } \\
\text { Man } \\
\text { female }\end{array}$ & $\begin{array}{l}67 \\
33\end{array}$ & $\begin{array}{l}67 \% \\
33 \%\end{array}$ \\
\hline $\begin{array}{l}\text { Monthly income } \\
\leq 1 \text { Million } \\
1-10 \text { Million } \\
10-20 \text { Million } \\
\geq 20 \text { Million }\end{array}$ & $\begin{array}{c}0 \\
43 \\
47 \\
10\end{array}$ & $\begin{array}{l}0 \% \\
43 \% \\
47 \% \\
10 \% \\
\end{array}$ \\
\hline $\begin{array}{l}\text { Level of education } \\
\text { Bachelor degree } \\
\text { strata } 2 \\
\text { more }\end{array}$ & $\begin{array}{c}9 \\
14 \\
77\end{array}$ & $\begin{array}{c}9 \% \\
14 \% \\
77 \%\end{array}$ \\
\hline
\end{tabular}

Sources: Primary data is processed, 2015

From Table 2 above, it is known that male respondents ie $67 \%$ more than female respondents only $33 \%$. Furthermore, respondents are grouped by age and it is known that the majority of respondents aged over 40 years is as much as $55 \%$. Then they were aged between $30-40$ years of as much as $45 \%$. While those aged 20-29 years as much as $0 \%$. By level of education, it is known that educated respondents S1 as many as $9 \%$. Then they were educated S2 as much as $14 \%$, and Others as much as $77 \%$. 
a. Cultural factors

Results can be obtained on average respondents' Cultural Factors, in the range of answers gave a score of 5 as much as $54 \%$, a score of 4 as much as $19 \%$, a score of 3 by $5 \%$, a score of 2 were $21 \%$ and 1 by $1 \%$. Here it can be concluded that on average most of the respondents continue to see the culture and social class can be relied upon in marketing the Toyota Avanza.

\section{b. Social factors}

Can be obtained by respondents about social factors, which averaged $41 \%$ of respondents gave a score of 5 , $45 \%$ of respondents gave a score of $4,4 \%$ gave a score of 3, $8 \%$ gave a score of 2 , and $0 \%$ of respondents who gave a score of 1 . Here it can be concluded that most respondents rate the social factor is one determinant in the decision to buy a car avanza.

c. individual characteristics

Results can be obtained on average respondents' individual characteristics, and as much as $19 \%$ of respondents strongly agree, agree in the range of $43 \%, 15 \%$ answered neutral, and respondents did not approve of as much as $32 \%$ strongly disagree and $20 \%$. Here it can be concluded that the average of the respondents think the individual characteristics may influence purchasing decisions Avanza cars in Makassar.

d. factors Psychology

Retrieved respondents about the level of community psychology, and as much as $51 \%$ of respondents strongly agree, agree in the range of $42 \%, 16 \%$ answered neutral, and respondents did not agree as much as $9 \%$ and strongly disagree $2 \%$. Here it can be concluded that the average of the respondents think psychological factors can affect car purchase decisions.

\section{e. Buying decision}

From the above table was obtained respondents' decision to buy a car Avanza, and as much as $51 \%$ of respondents strongly agree, agree in the range of $42 \%, 16 \%$ answered neutral, and respondents did not agree as much as $9 \%$ and strongly disagree $2 \%$. Here it can be concluded that the average of the respondents think psychological factors can affect car purchase decisions.

Based on the results of tests performed obtained values are listed in the following table:

Table 2 : coefficient Detrminasi

\begin{tabular}{|l|c|c|c|c|c|}
\hline Model & $\mathrm{R}$ & $\mathrm{R}$ Square & Adjusted R Square & $\begin{array}{c}\text { Std. Error of the } \\
\text { Estimate }\end{array}$ & $\begin{array}{c}\text { Durbin- } \\
\text { Watson }\end{array}$ \\
\hline & & & & & \\
\hline 1 &, $575(\mathrm{a})$ &, 331 & .303 & .47733 & 1673 \\
\hline
\end{tabular}

Source: The results of data processing SPSS, 2015

Based on the above table, we can see the results of multiple regression analysis as a whole shows the magnitude $\mathrm{R}^{2}=0.303$, which means $30.3 \%$ dependent variable is the Avanza car buying decision can be explained by the independent variables are the cultural, social, and psychological characteristics of the individual, while the remaining $69,7 \%$ is influenced by other variables outside variables used in the study. So we can conclude that the multiple linear regression model worthy of his research, because most of the dependent variable is explained by the independent variables used in the table.

Table 3: Simultaneous significance

\begin{tabular}{|l|l|r|r|r|r|c|}
\hline Model & & Sum of Squares & Df & mean Square & F & Sig. \\
\hline 1 & Regression & 10699 & 4 & 2675 & 11739 & $.000^{{ }^{\mathrm{a}}}$ \\
& residual & 21645 & 95 & .228 & & \\
& Total & 32344 & 99 & & & \\
\hline
\end{tabular}

The results of data processing SPSS, 2015

F test obtained calculated F value of 11.739 with probability 0.012 . Since the probability is much smaller than 0.005 , the regression model can be used to predict the frequency of cultural, social, and psychological characteristics of individuals jointly influence the purchasing decision of Toyota Avanza.

Table 4: Significance of Individual Parameters

\begin{tabular}{|c|c|c|c|c|c|}
\hline \multirow[b]{2}{*}{ Model } & \multicolumn{2}{|c|}{$\begin{array}{l}\text { unstandardized } \\
\text { Coefficients }\end{array}$} & $\begin{array}{l}\text { standardized } \\
\text { Coefficients }\end{array}$ & \multirow[b]{2}{*}{$\mathrm{t}$} & \multirow[b]{2}{*}{ Sig. } \\
\hline & B & Std. Error & beta & & \\
\hline (Constant) & .644 & .518 & & 1242 & .217 \\
\hline Culture & .009 & .082 & .010 & |.107. & .915 \\
\hline
\end{tabular}


Influence Factors Cultural Factors Social Factors Characteristic Individual And Psychological ..

\begin{tabular}{l|r|r|r|r|r|}
\hline Social & .081 & .084 & .087 & .963 & .338 \\
Karakteristik_individu & .173 & .091 & .179 & 1896 & .061 \\
Psychology & .541 & .104 & .479 & 5227 & .000 \\
\hline
\end{tabular}

The results of data processing SPSS, 2015

Of the three independent variables included in the regression model, the variables of cultural, social and psychological characteristics of individuals and significantly influence the purchasing decision of Toyota Avanza. Of the three independent variables included in the regression model, the variables of cultural, social and psychological characteristics of individuals and significantly influence the purchasing decision of Toyota Avanza. In this case turned out to be partially hypothesis, proved that:

Cultural factors positively influence the purchasing decision of Toyota Avanza car but not significant.

Social factors influence the purchasing decision porsitif against Toyota Avanza but ti insignificantly.

Factors Individual characteristics influence the purchasing decision porsitif against Toyota Avanza (as seen from the regression coefficients were significant at $\alpha=0.061$ ).

Psychological factors influence porsitif against terhada p Toyota Avanza car buying decision (as seen from the regression coefficients were significant at $\alpha=0.000$ ).

So that the relationship can be written in the form of equation regression models, namely:

$$
Y=0.644+0.009 X_{1} X_{2}+0081+0173+0541 X_{3} X_{4}
$$

$\mathrm{X} 1$ is a cultural factor, $\mathrm{X} 2$ is a social factor, $\mathrm{X} 3$ is a factor of individual characteristics, $\mathrm{X} 4$ is a psychological factor and $\mathrm{Y}$ is a car buying decision. As for the model interpretation of the above regression model is:

Constants sebeser 0644 states that if the independent variables are considered constant, then the average car purchase decisions for 0644 .

Cultural factors regression coefficient of 0.09 states that every $1 \%$ increase in the purchase decision variable cars will increase by $9 \%$.

Social factors regression coefficient of 0.081 states that every $1 \%$ increase in the purchase decision variable cars will increase by $8.1 \%$.

The regression coefficient of individual characteristic factor of 0.173 states that every $1 \%$ increase in the purchase decision variable cars will increase by $17.3 \%$.

The regression coefficient psychological factor of 0.541 states that every $1 \%$ increase in the purchase decision variable cars will increase by $54.1 \%$.

Cultural factors are variables that formed from various statements related to the sub-culture and social class. If seen from the questionnaire showed all questions were answered with the average value of 4 , the first hypothesis states that cultural factors significantly influence purchasing decisions Toyota Avanza car. Statistical tests showed that the regression coefficient cultural factors are not significant, suggesting that cultural factors affect positively but not significant to Toyota Avanza car buying decision.

Social factors are variables that formed from various statements related to the reference group, the family and the role of the status of all questions were answered with the average value of 3 , which means that social factors have an influence on purchasing decisions Toyota Avanza. The second hypothesis states that social factors significantly influence the purchasing decision of Toyota Avanza. Statistical tests showed that the value of the regression coefficient variable social factors are not significant, this suggests that social factors but not significant positive influence on purchasing decisions Toyota Avanza in Makassar.

Factor individual characteristics are variable formed from a variety of work related statements, ekonimi status, lifestyle and personality. Based on the results of questionnaires filled out by the parties involved, showing all the questions are answered with the average value of 4 , which means that the car buying decision is very dependent on the individual characteristics of a person. The third hypothesis states that a factor of individual characteristics significantly influence the purchasing decision of Toyota Avanza. Statistical tests showed that the regression coefficient is a significant factor individual characteristics, this suggests that social factors influence a positive and significant impact on the purchasing decision of Toyota Avanza in Makassar.

Psychological factors are variables that formed from various statements related to motivation, perception, learning, beliefs and attitudes. Based on the results of questionnaires filled out by the parties involved, showing all the questions are answered with the average value of 4 , which means that the car buying decision relies heavily on psychological factors. The fourth hypothesis states that psychological factors significantly influence the purchasing decision of Toyota Avanza. Statistical tests showed that the regression coefficient is a significant psychological factors, it does show that psychological factors and a significant positive influence on purchasing decisions Toyota Avanza in Makassar.

The results are consistent with the pious Muhammad S (2009) The influence of marketing mix on consumer purchasing decisions with research results show that there is a strong influence of psychological factors and factors of individual characteristics have on car buying decision. While the results of the study of cultural factors and social factors can not support the factors that influence the purchase decision. This is due to 
buy a product that the consumer is more likely to want a product to suit personal tastes and psychology of the consumers themselves. The results are consistent with the pious Muhammad S (2009) The influence of marketing mix on consumer purchasing decisions with research results show that there is a strong influence of psychological factors and factors of individual characteristics have on car buying decision.

While the results of the study of cultural factors and social factors can not support the factors that influence the purchase decision. This is due to buy a product that the consumer is more likely to want a product to suit personal tastes and psikol Ogi from consumers themselves.

From the results of testing the hypothesis by using multiple regression test can be summarized as follows: From the partial test results we concluded that cultural factors which consists of two dimensions, namely sub-cultures and social classes. but not significant positive effect on purchasing decisions Toyota Avanza car in Makassar. Testing the hypothesis for the variable social factors that consists of two dimensions used in this variable, namely the reference group, the family and the role of status, has a positive effect but not significant to the Toyota Avanza car purchasing decisions in Makassar. The test results of individual characteristic variables consisting of work-related dimensions, ekonimi status, lifestyle and personality, positive influence on the purchasing decision of Toyota Avanza in Makassar. The test results of psychological factors that comprise variable dimensions of motivation, perception, learning, beliefs and attitudes, positive influence on the purchasing decision of Toyota Avanza in Makassar.

While the simultaneous test results also showed that the four independent variables are cultural factors, social factors, individual characteristics factors and psychological factors that have an influence on purchasing decisions Toyota Avanza in Makassar.

Evaluation of the results of this study should consider the limitations that may affect the results of the study, including the difficulty of controlling the respondent. Further research can use other methods, or at least ensure the respondent is willing to cooperate. Based on the research that has been done then submitted suggestions, among others:

Future research should conduct a study using direct interview method to collect research data in order to reduce their weaknesses related to internal validity. Researchers also suggested for further research in order to expand the research object all the car dealers of various brands that exist dimakassar, so the results can be generalized. In this study, the independent variables studied variables affect the quality of the audit by $30.3 \%$, meaning that there is an impact for $69.7 \%$ of other variables outside the model. Future studies are recommended to investigate the influence of other variables that have not been included in the regression model in this study.

\section{Bibliography}

[1]. Mangkunagara Anwar Prabu, 2009. Consumer Behavior. Revised Edition. Publisher Revika Aditama: Bandung

[2]. Swastha, Basu., 1996. Azas Azas-Marketing. Third Edition. Publisher BPFE. Yogyakarta.

[3]. Kotler, Philip, 2000, Marketing Management: Analysis, Planning, Implementation and Control, Ninth Edition, Prentice Hall, Inc., Upper Saddle River, New Jersey.

[4]. Kotler and Armstrong. 2001. Principles of Marketing. Volume I, Eighth Edition, publisher, Jakarta.

[5]. Sugiyono. 2005. Business Research Methods. Publisher Alfabeta: Bandung.

[6]. Indriantoro, Nur, and Bambang Supomo. 2002. Business Research Methods for Accounting \& Management. First Edition, First Edition, BPFE.Yogyakarta 